\title{
Behavior and development of Tetranychus ludeni Zacher, 1913 (Acari: Tetranychidae) and physiological stress in genetically modified cotton expressing Cry1F and Cry1Ac proteins
}

\author{
N. R. Valadares $^{a}$ (D), M. A. Soares ${ }^{b *}$ (D), E. A. Ferreira ${ }^{b}$ (D), V. G. Mendes-Sác (D), \\ A. M. Azevedo ${ }^{a}$ (D), E. M. Pires ${ }^{d}$ (D) and G. L. D. Leite ${ }^{a}$ (D)
}

${ }^{a}$ Grupo de Estudos em Estatística e Experimentação Agrícola, Programa de Pós-graduação em Produção Vegetal, Instituto de Ciências Agrárias - ICA, Universidade Federal de Minas Gerais - UFMG, CEP 39404-547, Montes Claros, MG, Brasil



Received: April 12, 2019 - Accepted: March 13, 2020 - Distributed: May 31, 2021

(With 2 figures)

\begin{abstract}
Genetically modified plants are one of the tactics used in integrated pest management - IPM. There is great concern about the impact of these plants on non-target organisms. On the other hand, there is little information in the literature on the effects of transgenics (Bacillus thuringiensis) Bt on populations of phytophagous mites, and the physiological responses that this attack promotes on plants. The objective of this work was to evaluate the biology of the T. ludeni mite in Bt cotton, expressing the Cry1F and Cry1Ac proteins. To evaluate the behavior of food and oviposition preference of the $T$. ludeni with Bt cotton and isohybrid. Verify if the physiological stress caused by T. ludeni's attack is differentiated in Bt cotton. The mites were reared in Bt cotton and isohybrid, in a total of 40 replicates in the completely randomized design and the biological cycle was evaluated. The food preference and oviposition analysis were done with 10 replicates, with choice. The physiological stress was evaluated through chlorophyll fluorescence, under greenhouse conditions. The data of the T. ludeni biology were analyzed by Student's $\mathrm{t}$-test, for food and oviposition preference the chi-square test was performed. Regression models were fitted for the fluorescence parameters. The model identity test was used to evaluate the differences between Bt and isohybrid treatments. Cry1F and Cry1Ac proteins have not affected the biology of T. ludeni. The photosynthetic parameters in Bt cotton plants were less influenced by T. ludeni infestation.
\end{abstract}

Keywords: cotton, transgenic, spider mite.

\section{Comportamento e desenvolvimento de Tetranychus ludeni Zacher, 1913 (Acari: Tetranychidae) e estresse fisiológico em algodoeiro geneticamente modificado expressando as proteínas Cry1F e Cry1Ac}

\begin{abstract}
Resumo
O uso de plantas geneticamente modificadas é uma das táticas utilizadas no manejo integrado de pragas - MIP. Observa-se grande preocupação com o impacto dessas plantas sobre organismos não alvos. Por outro lado, existe pouca informação na literatura sobre efeitos dos transgênicos (Bacillus thuringiensis) Bt em populações de ácaros fitófagos, e as respostas fisiológicas que esse ataque promove nas plantas. Objetivou-se com esse trabalho avaliar a biologia do ácaro $T$. ludeni em algodoeiro Bt, expressando as proteínas Cry1F e Cry1Ac. Avaliar se há comportamento de preferência alimentar e postura de T. ludeni em relação ao algodoeiro Bt e seu iso-híbrido. E verificar se o estresse fisiológico causado pelo ataque de T. ludeni é diferenciado em algodoeiro Bt. Os ácaros foram criados em algodoeiro Bt e iso-híbrido, em um total de 40 repetições no delineamento inteiramente casualizado, onde foi avaliado o ciclo biológico. A análise de preferência alimentar e de posturas foi feita com 10 repetições, com escolha. O estresse fisiológico foi avaliando através da fluorescência da clorofila, em casa de vegetação. Os dados da biologia de T. ludeni foram analisados pelo teste $\mathrm{t}$ Student, para preferência alimentar e postura foi realizado o teste qui-quadrado. Para os parâmetros da fluorescência,
\end{abstract}


foram ajustados modelos de regressão. Para testar as diferenças entre Bt e iso-híbrido foi utilizado o teste de identidade de modelos. As proteínas Cry1F e Cry1Ac não afetaram a biologia de T. ludeni. Os parâmetros fotossintéticos em plantas de algodoeiro Bt foram menos influenciados pela infestação de T. ludeni.

Palavras-chave: algodão, transgenia, ácaro.

\section{Introduction}

Cotton cultivation is one of the main activities for agriculture in Brazil, being the fifth largest producer in the world, with a cultivated area of approximately 1.6 million hectares (CONAB, 2019). The national production of cotton is primarily aimed at the textile industry, and the main concern is fiber quality, to meet the requirements of domestic industries and external customers.

Several species of mites can cause significant reductions in cotton fiber quality and production. The red mite Tetranychus ludeni Zacher, 1913 (Acari: Tetranychidae) is widely distributed to the producing countries. Mites are specialized in feeding the cytoplasmic content of cells, destroyed them (Fadini et al., 2012). Herbivorous mites are among the most important pests across the world (Castro et al., 2019). The use of transgenic plants expressing insecticidal proteins could affect or alter the biology and development of non-target organisms, such as mites. This is a concern often associated with the use of plants (Bacillus thuringiensis) Bt, their possible negative influence on non-target organisms (Becker et al., 2014).

The use of genetically modified plants is one of the tactics of integrated pest management - IPM, allows the reduction of the number of applications of chemical-synthetic insecticides and promotes more effective pest control (Sharma and Ortiz, 2000). Among the transgenic crops cultivated in Brazil, we highlight the Bt cotton, event 281-24-236/3006-210-23 (WideStrike ${ }^{\mathrm{TM}}$ ). In addition to insect resistance through the action of the cry $1 F$ and crylAc genes, the event also shows resistance to the herbicide glufosinate-ammonium due to the presence of two copies of the pat gene (Streptomyces viridochromogenes) (CTNBIO, 2016).

There is little information in the literature on the effects of Bt transgenics on mite populations and the stress caused on that plant due to the damage caused by the attack. These factors affect plant growth, and in genetically modified organisms can prevent gene expression (Kalaji and Guo, 2008).

This study aimed to evaluate the biology of T. ludeni in genetically modified cotton, investigating whether the $\mathrm{Bt}$ proteins associated with this product have any effect on these non-target organisms. To evaluate the behavior of food and oviposition preference of the T. ludeni with Bt cotton and isohybrid. To verify the physiological stress caused by T. ludeni's attack is differentiated in Bt cotton.

\section{Material and Methods}

The experiments were conducted in a greenhouse and at the Entomology Laboratory of the Federal University of the Jequitinhonha and Mucuri Valleys - UFVJM. The mites were removed from laboratory mass rearing and submitted to two treatments, the Bt cotton 281-24-236/3006-210-23 and the isohybrid cotton.

The cotton seeds were planted in polyethylene containers of $5 \mathrm{~L}$, with soil fertilized according to recommendations for containers (Malavolta, 1980), maintaining two plants per container, in a total of 30 replicates for each treatment, to obtain leaves. The cotton plants were cultivated in the greenhouse.

\subsection{Obtaining the biological data of T. ludeni}

The biological cycle, the viability of the eggs and the survival of the stages of development for T. ludeni were evaluated. A total of 40 replicates were used in a completely randomized design. The evaluations were made in incubator type B.O.D. at $25 \pm 1{ }^{\circ} \mathrm{C}, 60 \pm 5 \%$ relative humidity and $12 \mathrm{~h}$ photophase.

The development and reproduction of T. ludeni on leaf discs with $5 \mathrm{~cm}$ in diameter of Bt cotton and the isohybrid were observed for one generation. For the preparation of the discs, leaves from the median part of the cotton plants were used, with 35 to 60 days old (Esteves-Filho et al., 2010).

The discs were placed on a moistened polyethylene sponge saturated with distilled water and kept in gerbox type plates (Esteves-Filho et al., 2010). To avoid the escape of the mites, the discs were surrounded by cotton moistened with water.

Each disc received five adult females of T. ludeni, which remained in the arenas (leaf of the cotton plant) during 16 hours, for oviposition. Then, the females were removed from the discs, the eggs were quantified, and only two eggs were left in the arena (Silva et al., 2005).

Eggs viability was calculated by the difference between the number of eggs left in the arenas and the number of eggs not hatched. For the incubation and the development phase duration, daily evaluations were performed.

After emergence, the females were mated with males obtained from the mass rearing, and the number of eggs produced and the adults' longevity was evaluated daily.

\subsection{Food preference and oviposition behavior test of T. ludeni}

The food preference and oviposition behavior of T. ludeni were evaluated in incubator type B.O.D. at $25 \pm 1{ }^{\circ} \mathrm{C}$, $60 \pm 5 \%$ relative humidity and $12 \mathrm{~h}$ photophase. For the evaluation, leaf discs with $5 \mathrm{~cm}$ diameter were obtained from the central part of leaves of Bt cotton and the isohybrid. The discs were placed side by side and connected by a plastic cover. This set was placed on a sponge saturated with water, inside plastic plates (gerbox).

Six females of T. ludeni, obtained from the laboratory mass rearing, were released in the medial portion of the 
plastic cover. After the mites releasing, the gerbox plates were incubated in the B.O.D. and after $24 \mathrm{~h}$, the number of females and laid eggs were evaluated. To evaluate the food preference of T. ludeni the treatments Bt vs Bt, Bt vs isohybrid and isohybrid vs isohybrid were proposed. Were evaluated 10 repetitions per treatment (Esteves-Filho et al., 2010).

\subsection{Evaluation of the physiological stress of cotton}

After the occurrence of a natural infestation of T. ludeni in greenhouse cotton plants, the physiological stress was evaluated using a fluorometer (Mini-Pam-2014, Heinz-Walz), with 30 repetitions. The tweezers of the fluorescence measuring device were placed in the middle of the third fully expanded cotton leaves, where the initial fluorescence, maximum fluorescence, the ratio between variable and maximum fluorescence, and the rate of electron transport were obtained. Measurements were taken after 30 minutes of adaptation to the dark (Ferreira et al., 2015).

The severity of $T$. ludeni infestation was evaluated. According to the number of adult mites present in the leaves, different damage scores were awarded. Score 1 was assigned to non-infested leaves (zero mites), score 2 to infested leaves ( $\leq 100$ mites), and score 3 to heavily infested leaves ( $>100$ mites).

\subsection{Statistical analyzes}

The biological data were analyzed by Student's T-test. For food and oviposition preference, the chi-square test was performed, both using the computer program $\mathrm{R}$ through the functions t.test and chisq.test, respectively. Survival curves for the juvenile and adult phases were determined using the Kaplan-Meyer estimator. For the analysis of chlorophyll fluorescence data, the simple linear regression model was adjusted. To verify if the adjusted regressions for Bt cotton and its isohybrid are statistically equal, the model identity test was used. In this test, the equality of the regression coefficients (B0 and B1) was assumed as the null hypothesis. Details on this statistical methodology are presented by Cruz et al. (2014).

\section{Results}

There was no difference observed on development of larva, protonymph, deutonymph, longevity of adults and duration of egg to adult for T. ludeni reared in Bt cotton and isohybrid (Table 1).

No differences were observed for the characteristics evaluated in the adult phase: number of eggs per female, egg viability, incubation period, number of eggs per female of first-generation, pre-oviposition, oviposition and post-oviposition period for both treatments (Table 2).

Kaplan-Meyer survival curves showed the same behavior for both varieties studied (Figure 1). It was found a high mortality rate in the immature phase, individuals that passed into adulthood had a lower mortality rate until the cycle was completed, characterizing a type III curve (Ricklefs, 2011). The adults reared on Bt cotton discs survived for six days longer than isohybrid.

In the tests of food and oviposition preference, there was also no difference for Bt vs. Bt, Bt vs. isohybrid and isohybrid vs. isohybrid (Table 3). Thus, no food and oviposition preference were observed for $T$. ludeni to $\mathrm{Bt}$ cotton and isohybrid.

The model identity test did not detect differences between $\mathrm{Bt}$ cotton and isohybrid as a function of T. ludeni infestation for initial fluorescence (Fo), maximum fluorescence (Fm), variable fluorescence/maximum fluorescence ratio $(\mathrm{Fv} / \mathrm{Fm})$, and electron transport rate (ETR) (Table 4).

Table 1. Mean duration, in days, of the stages of development and Student's t-test (t-Estimate) of Tetranychus ludeni reared on Bt cotton and isohybrid.

\begin{tabular}{lrrcc}
\hline \multicolumn{1}{c}{ Stages } & Bt & Isohybrid & t-Estimate & p-value \\
\hline Larva & $2.800 \pm 0.140$ & $2.775 \pm 0.098$ & 0.147 & 0.884 \\
Protonymph & $2.000 \pm 0.136$ & $1.920 \pm 0.162$ & 0.378 & 0.707 \\
Deutonymph & $3.000 \pm 0.277$ & $2.867 \pm 0.256$ & 0.353 & 0.727 \\
Longevity of adults & $11.000 \pm 3.246$ & $9.714 \pm 2.447$ & 0.316 & 0.756 \\
Egg - Adult & $14.350 \pm 3.525$ & $13.500 \pm 2.490$ & 0.197 & 0.847 \\
\hline
\end{tabular}

Note: $\mathrm{p}$-value $=$ evidence against a null hypothesis.

Table 2. Number of eggs per female, egg viability, incubation period, number of eggs per female of the first-generation, pre-oviposition, oviposition, post-oviposition period and Student's t-test (t-Estimate) of Tetranychus ludeni reared on Bt cotton and isohybrid.

\begin{tabular}{lrrcc}
\hline \multicolumn{1}{c}{ Feature } & \multicolumn{1}{c}{ Bt } & \multicolumn{1}{c}{ Isohybrid } & t Estimate & p-value \\
\hline N. of eggs/ $/+$ & $1.415 \pm 0.112$ & $1.225 \pm 0.100$ & 1.266 & 0.210 \\
Egg viability & $64.000 \pm 5.491$ & $60.000 \pm 5.591$ & 0.488 & 0.627 \\
Incubation period & $4.486 \pm 0.093$ & $4.391 \pm 0.083$ & 0.763 & 0.448 \\
Total eggs $/{ }^{\mathrm{a}} \mathrm{G}$ & $24.857 \pm 4.383$ & $29.000 \pm 1.080$ & -0.929 & 0.408 \\
Pre-oviposition & $1.333 \pm 0.333$ & $1.500 \pm 0.289$ & -0.378 & 0.715 \\
Oviposition & $14.167 \pm 4.061$ & $10.500 \pm 2.327$ & 0.783 & 0.458 \\
Post-oviposition & $0.833 \pm 0.307$ & $1.000 \pm 0.408$ & -0.326 & 0.755 \\
\hline
\end{tabular}

Note: $\mathrm{p}$-value $=$ evidence against a null hypothesis 
Figure 2a shows the curves referring to Fo, showing the behavior of each treatment concerning the severity of the infestation. No significance was observed for B0,

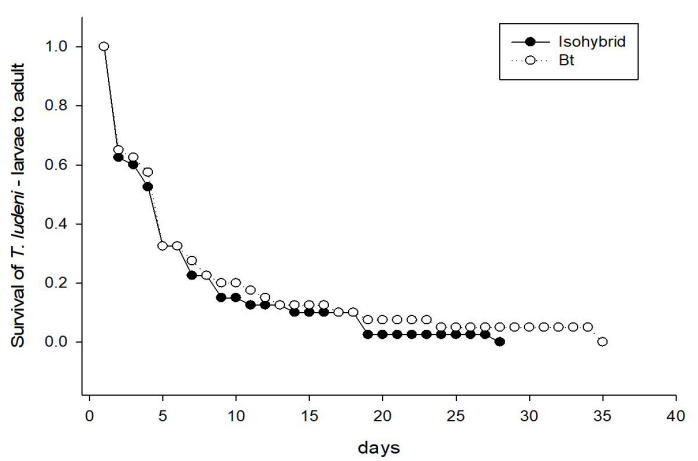

Figure 1. Survival curves, obtained by the Kaplan-Meyer estimator, of individuals of Tetranychus ludeni reared on leaf discs of Bt cotton and isohybrid.

Table 3. Result of Chi-square test $\left(\mathrm{X}^{2}\right)$ for food and oviposition preference of Tetranychus ludeni submitted to Bt cotton and isohybrid, with option of choice.

\begin{tabular}{lcclcc}
\hline \multirow{2}{*}{ Trat. } & \multicolumn{2}{c}{ Food } & & \multicolumn{2}{c}{ Oviposition } \\
\cline { 2 - 3 } \cline { 5 - 6 } & $\mathbf{X}^{2}$ & p-value & & $\mathbf{X}^{\mathbf{2}}$ & p-value \\
\hline Bt vs. Bt & 0.154 & 0.695 & & 0.600 & 0.438 \\
Bt vs. Isohybrid & 1.000 & 0.317 & & 0.053 & 0.818 \\
Isohybrid vs. & 0.571 & 0.449 & & 3.769 & 0.052 \\
Isohybrid & & & & & \\
\hline
\end{tabular}

Note: $\mathrm{p}$-value $=$ evidence against a null hypothesis. indicating an absence of effect on Fo as a function of the increment of the mite infestation for the evaluated treatments. Although there was no significance for the angular coefficient of the line (B0), there was a tendency for an increase in the Fo due to the increase in the severity of $T$. ludeni infestation in the isohybrid.

When evaluating the variables maximum fluorescence (Figure 2b), variable fluorescence ratio and maximum fluorescence (Figure 2c) and electron transport rate (Figure 2d), a similar behavior was observed, with a tendency to decrease in the values with the increase of the T. ludeni infestation. Both Bt cotton and isohybrid presented lower values of $\mathrm{Fv} / \mathrm{Fm}$, in the high severity condition (Figure 2c). It was observed that there was a significant effect (B0) of T. ludeni infestation on the $\mathrm{Fv} / \mathrm{Fm}$ and ETR ratio for the isohybrid (Figure $2 \mathrm{c}$ and $2 \mathrm{~d}$ ). However, Bt cotton was not affected by infestation levels (B0 not significant), presenting stable behavior for all photosynthetic parameters (Figure 2).

\section{Discussion}

Cry1F and Cry1Ac toxins produced by Bt cotton did not affect the duration of immature stages, adult longevity and egg to adult duration in T. ludeni. Similar results were found for Tetranychus urticae Koch, 1836 (Acari: Tetranychidae), with no differences for the immature stages, adult longevity and the egg to adult period for mites submitted to Bt cotton treatments expressing the Cry1Ac protein (Esteves-Filho et al., 2010). Guo et al. (2016) obtained the same conclusions in studies with

Table 4. Scheme of analysis of variance relative to the model identity test, considering as null hypothesis the equality of the two adjusted regression models for the variables initial fluorescence, maximum fluorescence, relation between variable and maximum fluorescence and electron transport rate in function of the degree of infestation of Tetranychus ludeni.

\begin{tabular}{|c|c|c|c|c|c|}
\hline \multicolumn{6}{|c|}{ Initial fluorescence (Fo) } \\
\hline FV & GL & SQ & QM & $\mathbf{F}$ & p-value \\
\hline Model (Full) & 4 & $2,791,302.180$ & - & - & - \\
\hline Model (Reduced) & 2 & $2,665,805.180$ & - & - & - \\
\hline Reduction (Ho) & 2 & $125,497.010$ & $62,748.504$ & 4.660 & 0.177 \\
\hline Residue & 6 & $26,928.780$ & $13,464.391$ & - & - \\
\hline \multicolumn{6}{|c|}{ Maximum fluorescence (Fm) } \\
\hline Model (Full) & 4 & $37,638,964.800$ & - & - & - \\
\hline Model (Reduced) & 2 & $37,615,317.020$ & - & - & - \\
\hline Reduction (Ho) & 2 & $23,647.780$ & $11,823.892$ & 0.573 & 0.636 \\
\hline Residue & 6 & $41,242.840$ & $20,621.422$ & - & - \\
\hline \multicolumn{6}{|c|}{ Variable fluorescence/maximum fluorescence (Fv/Fm) } \\
\hline Model (Full) & 4 & 3.196 & - & - & - \\
\hline Model (Reduced) & 2 & 3.195 & - & - & - \\
\hline Reduction (Ho) & 2 & 0.002 & 0.001 & 1.532 & 0.395 \\
\hline Residue & 6 & 0.001 & 0.001 & - & - \\
\hline \multicolumn{6}{|c|}{ Electron transport rate (ETR) } \\
\hline Model (Full) & 4 & $6,540.549$ & - & - & - \\
\hline Model (Reduced) & 2 & $6,540.549$ & - & - & - \\
\hline Reduction (Ho) & 2 & 76.318 & 38.159 & 15.794 & 0.060 \\
\hline Residue & 6 & 4.832 & 2.416 & - & - \\
\hline
\end{tabular}

Note: $\mathrm{FV}=$ Source of variation; $\mathrm{GL}=$ degrees of freedom; $\mathrm{SQ}=$ sum of squares; $\mathrm{QM}=$ mean squares; $\mathrm{F}=$ test statistic, $\mathrm{p}$-value $=$ evidence against a null hypothesis . 

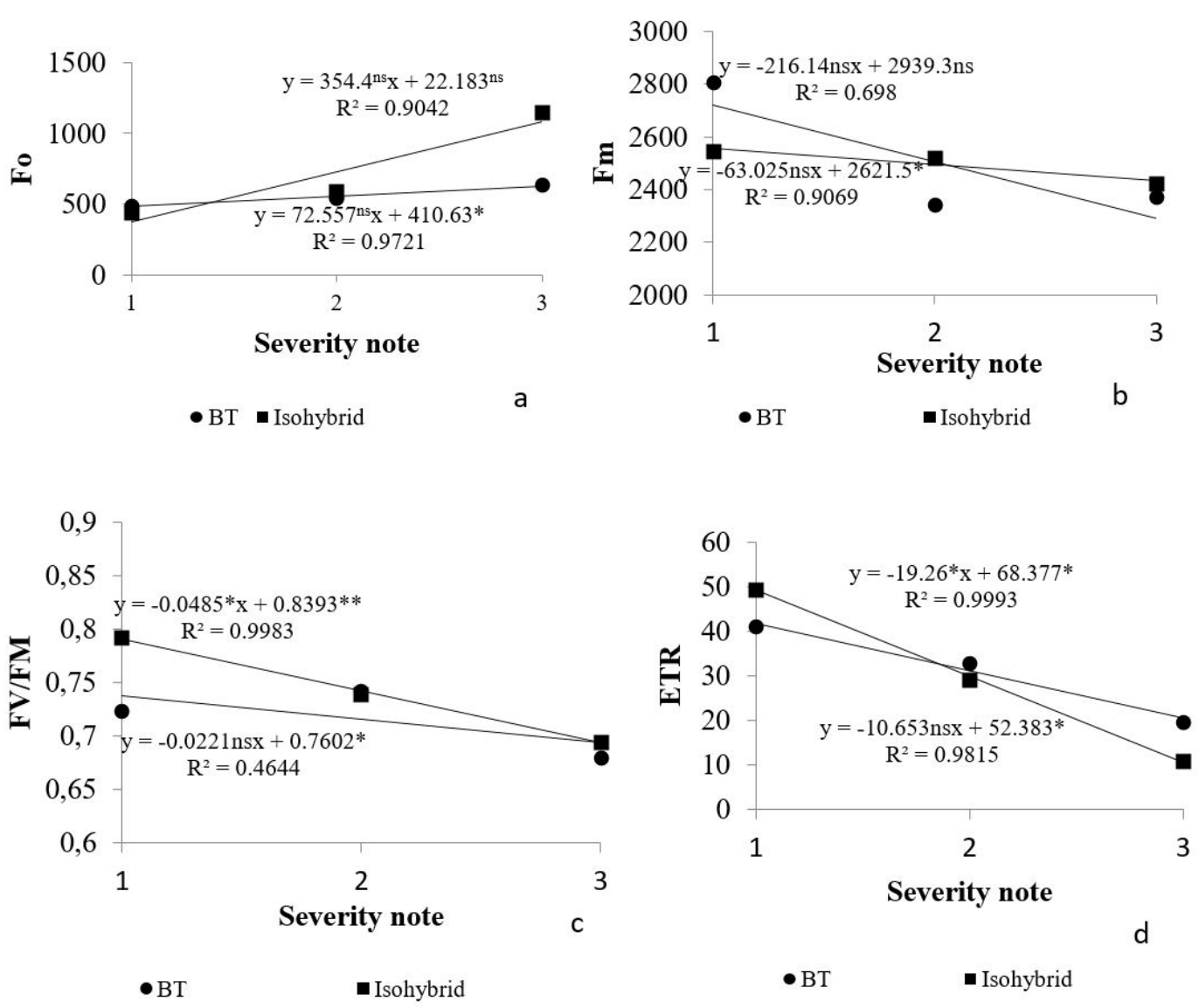

Figure 2. Regression model for initial fluorescence (Fo- Figure a), maximum fluorescence (Fm- Figure b), ratio between variable and maximum fluorescence (Fv/Fm- Figure c) and electron transport rate (ETR- Figure d) in Bt cotton and isohybrid as a function of grades of infestation severity of Tetranychus ludeni: $1=$ zero; $2=\leq 100 ; 3=>100$ mites/leaf.

the CrylF toxin, finding no impacts for the biology of T. urticae mites. The results obtained in this work provide strong evidence that this technology, including pyramidal hybrids, is safe for the non-target organisms in question.

The averages found for the characteristics evaluated in the adult phase show that there is no effect of the Cry toxins in T. ludeni. Contrary results verified that alterations caused in the secondary metabolism of Bt cotton plants were responsible for the reduction in generation time and increase in the number of eggs of mites Tetranychus cinnabarinus Boisduval, 1987 (Acari: Tetranychidae) and Tetranychus truncatus Ehara, 1956 (Acari: Tetranychidae) (Ma et al., 2014).

The observed behavior for survival curves is expected for mites since a type III survival curve results from high mortality in early life due to the vulnerability of young individuals (Ricklefs, 2011). The survival of phytophagous organisms is directly linked to the quality of the host plant. Survival curves show the same behavior for mites reared in Bt and isohybrid plants. Esteves-Filho et al. (2010) evaluating the biology and behavior of T. urticae mites obtained similar results, with no difference for survival in $\mathrm{Bt}$ cotton plants and isohybrid cotton. However, the T. ludeni adults reared on Bt cotton leaf discs survived longer than in the isohybrid, although without statistical differences in the average longevity in the different treatments. The prolonged survival of some T. ludeni individuals in Bt treatment may be related to changes in secondary metabolism caused by the addition of genes. Considering that the insertion of $\mathrm{Bt}$ genes into cotton plants may promote changes in secondary compounds associated with plant-herbivore interaction (Yan et al., 2004).

Studies on the effects of Cry proteins expressed by transgenic plants on populations of phytophagous mites are still incipient but have shown that these organisms are generally unaffected, despite the high exposure through acquisition and accumulation of the protein in their body and the fact that the protein remains active after ingestion (Obrist et al., 2006).

Tetranychus ludeni did not present food and oviposition preferences with Bt cotton and isohybrid plants. According to Rovenská et al. (2005) T. urticae mites preferred transgenic plants for feeding and laying eggs relative to conventional plants. Li et al. (2014) reported that mites Tetranychus turkestani Tetrtk, 1937 (Acari: Tetranychidae) preferred to feed and lay eggs in conventional plants than in transgenics. Few studies and the complexity of adequacy of the trials may be the reasons for variations in results 
and difficulty of comparisons. But it must be considered that the behavior of the mites can be influenced by the constitutive characteristics of the plants, which include their allelochemicals and the toxins expressed.

Thus, the results presented in this study provide evidence that $\mathrm{Bt}$ technologies containing the $c r y l F$ and cry $1 A c$ genes do not affect $T$. ludeni populations. One of the great advantages of the use of genetically modified organisms - GMOs is the reduction in the use of insecticides, which allows the use of this tactic with biological control. Populations of phytophagous mites that develop in $\mathrm{Bt}$ cotton could be controlled and kept below the level of economic damage by their natural enemies, such as the predator mite Phytoseiulus macropilis Banks, 1904 (Acari: Phytoseiidae) already associated with $T$. ludeni (Reichert et al., 2017; Castro et al., 2014), and the cotton crop (Esteves-Filho et al., 2010) in the literature.

In the evaluation of the physiological stress, higher values of Fo may indicate structural damage in the reaction centers of Photosystem II or compromise in the transport of excitation energy from the antenna complexes to the reaction centers (Cruz et al., 2009). The accessory pigments such as chlorophyll-a, $\mathrm{b}$ are part of the antenna complex and have as their main function to absorb the photons and transfer the energy to the reaction center complex (Bolhàr-Nordenkampf et al., 1989). Thus, damage to the photosynthetic apparatus may have occurred in the cotton plants of the isohybrid treatment, because of $T$. ludeni infestation. This is because feeding of mites damages directly the photosynthetic cell apparatus (Aldea et al., 2005).

The maximum quantum yield of photosystem II $(\mathrm{Fv} / \mathrm{Fm})$ is determinant for the identification of a biotic stress (Kalaji and Guo, 2008). It may vary from 0.75 to 0.85 in plants not subjected to stress (Bolhàr-Nordenkampf et al., 1989). Values below 0.75 indicate stress and reduced photosynthetic potential of the plant (Ferreira et al., 2015). Which was observed for the Bt cotton and isohybrid attacked by the mite. Huang et al. (2013) state that under low infestation of sucking insects, the photochemical reactions and the ETR are not very affected, however, when there is a high infestation and a long period of interaction between herbivore-plant, the fluorescence parameters are negatively influenced, which occurred with $\mathrm{Fm}, \mathrm{Fv} / \mathrm{Fm}$, and ETR.

Bt plants were less affected by the severity of the mite infestation, presenting less biotic stress and this can be an advantage. Since mites feed on cellular cytoplasmic content, directly damaging the cell's photosynthetic apparatus and indirectly the gas exchanges, by interrupting the transport of nutrients and water (Aldea et al., 2005). This attack causes a reduction in the photosynthetic rate and lower leaf growth of the plant (Velikova et al., 2010), chlorosis and premature loss of leaves, with a consequent decrease in productivity (Li et al., 2013). The use of GMOs has increasing in agriculture, especially in countries like Brazil, which due to its extensive territorial area and favorable climate has the potential to increase the production efficiency.

\section{Conclusions}

The Cry $1 \mathrm{~F}$ and Cry $1 \mathrm{Ac}$ proteins constitutively present in $\mathrm{Bt}$ cotton did not affect the biological and behavioral parameters of $T$. ludeni mites in this study.

The photosynthetic parameters in Bt cotton plants were less influenced by T. ludeni infestation. The isohybrid showed higher physiological stress in the high severity of infestation.

\section{Acknowledgements}

To the Brazilian agencies "Conselho Nacional de Desenvolvimento Cientifico e Tecnológico (CNPq)" and "Fundação de Amparo à Pesquisa do Estado de Minas Gerais (FAPEMIG)" for scholarships and financial support. This study was financed in part by the "Coordenação de Aperfeiçoamento de Pessoal de Nível Superior - Brasil (CAPES)" - Finance Code 001.

\section{References}

ALDEA, M., HAMILTON, J.G., RESTI, J.P., ZANGERL, A.R., BERENBAUM, M.R. and EVAN, H.D., 2005. Indirect effects of insect herbivory on leaf gas exchange in soybean. Plant, Cell \& Environment, vol. 28, no. 3, pp. 402-411. http://dx.doi. org/10.1111/j.1365-3040.2005.01279.x.

BECKER, R., BUBNER, B., REMUS, R., WIRTH, S. and ULRICH, A., 2014. Impact of multi-resistant transgenic Bt maize on straw decomposition and the involved microbial communities. Applied Soil Ecology, vol. 73, pp. 9-18. http://dx.doi.org/10.1016/j. apsoil.2013.08.002.

BOLHAR-NORDENKAMPF, H.R., LONG, S.P., BAKER, N.R., OQUIST, G., SCHREIBER, U. and LECHNER, E.G., 1989. Chlorophyll fluorescence as a probe of the photossinthetic competence of leaves in the field. Functional Ecology, vol. 3, no. 4, pp. 497-514. http://dx.doi.org/10.2307/2389624.

CASTRO, B.M.C., SOARES, M.A., ANDRADE JÚNIOR, V.C., SANTOS JÚNIOR, V.C., FONTES, P.C.R., WILCKEN, C.F., SERRÃO, J.E. and ZANUNCIO, J.C., 2019. Preference of red mite Tetranychus ludeni Zacher (Acari: Tetranychidae) to sweet potato genotypes. Brazilian Journal of Biology $=$ Revista Brasileira de Biologia, vol. 79, no. 2, pp. 208-212. http://dx.doi. org/10.1590/1519-6984.176665. PMid:29947646.

CASTRO, B.M.C., SOARES, M.A., ANDRADE-JÚNIOR, V.C., FADINI, M.A.M., FERREIRA, J.A.M. and MORAES, G.J.D., 2014. The predatory mite Phytoseiulus macropilis (Acari: Phytoseiidae) occurring on sweet potato (Ipomoea batatas) plants in Diamantina, Minas Gerais State, Brazil. Brazilian Journal of Biology $=$ Revista Brasileira de Biologia, vol. 74, no. 3, pp. 685686. http://dx.doi.org/10.1590/bjb.2014.0078. PMid:25296218.

COMISSÃO TÉCNICA NACIONAL DE BIOSSEGURANÇACTNBIO, 2016 [viewed 12 April 2019]. Liberações comerciais: parecer técnico $n^{\circ}$ 1757-2009 [online]. Available from: http:// ctnbio.mcti.gov.br/liberacao-comercial

COMPANHIA NACIONAL DE ABASTECIMENTO - CONAB, 2019 [viewed 12 April 2019]. Algodão: análise mensal: fevereiro 2019 [online]. Available from: http://www.conab.gov.br 
CRUZ, C.D., REGAZZI, A.J. and CARNEIRO, P.C.S., 2014. Modelos biométricos aplicados ao melhoramento genético. Viçosa: Editora UFV, 2 vol.

CRUZ, M.D., SIQUEIRA, D.D., SALOMÃO, L.C.C. and CECON, P.R., 2009. Fluorescência da clorofila a em folhas de tangerineira 'Ponkan' e limeira ácida 'Tahiti' submetidas ao estresse hídrico. Revista Brasileira de Fruticultura, vol. 31, no. 3, pp. 896-901. http://dx.doi.org/10.1590/S0100-29452009000300037.

ESTEVES FILHO, A.B., OLIVEIRA, J.V., TORRES, J.B. and GONDIM JÚNIOR, J.R.M.G., 2010. Biologia comparada e comportamento de Tetranychus urticae Koch (Acari: Tetranychidae) e Phytoseiulus macropilis (Banks) (Acari: Phytoseiidae) em algodoeiro Bollgard ${ }^{\mathrm{TM}}$ e Isolinha não-Transgênica. Neotropical Entomology, vol. 39, no. 3, pp. 338-344. http://dx.doi.org/10.1590/ S1519-566X2010000300005. PMid:20676505.

FADINI, M.A.M., ARAUJO, O.G., MARTINS MENDES, S. and MARINHO, C.G.S., 2012. Ocorrência do ácaro fitófago Catarhinus tricholaenae Keifer (Acari: Diptilomiopidae) em cultivares de milho Bt. Ciência Rural, vol. 42, no. 9, pp. 1524-1527. http:// dx.doi.org/10.1590/S0103-84782012000900001.

FERREIRA, E.A., MATOS, C.D.C., BARBOSA, E.A., SILVA, D.V., SANTOS, J.B., PEREIRA, G.A.M., FARIA, A.T. and SILVA, C.T., 2015. Respostas fisiológicas da mandioca à aplicação de herbicidas. Semina: Ciências Agrárias, vol. 36, no. 2, pp. 645-656. http://dx.doi.org/10.5433/1679-0359.2015v36n2p645.

GUO, Y.-Y., TIAN, J.-C., SHI, W.-P., DONG, X.-H., ROMEIS, J., NARANJO, S.E., HELLMICH, R.L. and SHELTON, A.M., 2016. The interaction of two-spotted spider mites, Tetranychus urticae Koch, with Cry protein production and predation by Amblyseius andersoni (Chant) in Cry1 Ac/Cry2 Ab cotton and Cry1F maize. Transgenic Research, vol. 25, no. 1, pp. 33-44. http://dx.doi.org/10.1007/s11248-015-9917-1. PMid:26545599.

HUANG, J., ZHANG, P.J., ZHANG, J., LU, Y.B., HUANG, F. and LI, M.J., 2013. Chlorophyll content and chlorophyll fluorescence in tomato leaves infested with an invasive Mealybug, Phenacoccus solenopsis (Hemiptera: pseudococcidae). Environmental Entomology, vol. 42, no. 5, pp. 973-979. http://dx.doi.org/10.1603/EN12342. PMid:24073741

KALAJI, M.H. and GUO, P., 2008. Chlorophyll fluorescence: a useful tool in barley plant breeding programs. In: A. SANCHEZ and S. J. GUTIERREZ, eds. Photochemistry research progress. New York: Nova Publishers, pp. 439-463.

LI, G.Y., LI, J.J., XIA, W., QU, H.L., YANG, S. and ZHANG, J.P., 2014. Effects of Bt plus CpTI transgenic cotton on the performance of Tetranychus turkestani (Acari: tetranychidae). Systematic and Applied Acarology, vol. 19, no. 2, pp. 236-247. http://dx.doi.org/10.11158/saa.19.2.14.

LI, Q., TAN, W., XUE, M., ZHAO, H. and WANG, C., 2013. Dynamic changes in photosynthesis and chlorophyll fluorescence in Nicotiana tabacum infested by Bemisia tabaci (Middle East-
Asia Minor 1) nymphs. Arthropod-Plant Interactions, vol. 7, no. 4, pp. 431-443. http://dx.doi.org/10.1007/s11829-013-9260-5.

MA, H., ZHAO, M., WANG, H., WANG, Z., WANG, Q. and DONG, H., 2014. Comparative incidence of cotton spider mites on transgenic Bt versus conventional cotton in relation to contents of secondary metabolites. Arthropod-Plant Interactions, vol. 8, no. 1, pp. 1-7. http://dx.doi.org/10.1007/s11829-014-9291-6.

MALAVOLTA, E., 1980. Elementos de nutrição mineral de plantas. São Paulo: Agronômica Ceres.

OBRIST, L.B., DUTTON, A., ROMEIS, J. and BIGLER, F., 2006. Biological activity of Cry $1 \mathrm{Ab}$ toxin expressed by Bt maize following ingestion by herbivorous arthropods and exposure of the predator Chrysoperla carnea. BioControl, vol. 51, no. 1, pp. 31-48. http://dx.doi.org/10.1007/s10526-005-2936-8.

REICHERT, M.B., TOLDI, M., RODE, P.A., FERLA, J.J. and FERLA, N.J., 2017. Biological performance of the predatory mite Neoseiulus idaeus (Phytoseiidae): a candidate for the control of tetranychid mites in Brazilian soybean crops. Brazilian Journal of Biology $=$ Revista Brasileira de Biologia, vol. 77, no. 2, pp. 361366. http://dx.doi.org/10.1590/1519-6984.14915. PMid:27533728.

RICKLEFS, R.E. 2011. A economia da natureza. Rio de Janeiro: Guanabara Koogan, 546 p. no. 6.

ROVENSKÁ, G.Z., ZEMEK, R., SCHIMIDT, J.E.U. and HILBECK, A., 2005. Altered host plant preference of Tetranychus urticae and prey preference of its predator Phytoseiulus persimilis (Acari: Tetranychidae, Phytoseiidae) on transgenic Cry3Bb-eggplants. Biological Control, vol. 33, no. 3, pp. 293-300. http://dx.doi. org/10.1016/j.biocontrol.2005.03.017.

SHARMA, H.C. and ORTIZ, R., 2000 [viewed 12 April 2019]. Transgenics, pest management, and the environment. Current Science [online], vol. 79, no. 4, pp. 521-437. Available from: http://www.jstor.org/stable/24104411

SILVA, F.R., VASCONCELOS, G.J.N., GONDIM JÚNIOR, M.G.C. and OLIVEIRA, J.V., 2005. Exigências térmicas e tabela de vida de fertilidade de Phytoseiulus macropilis (Banks) (Acari: phytoseiidae). Neotropical Entomology, vol. 34, no. 2, pp. 291-296. http://dx.doi.org/10.1590/S1519-566X2005000200017.

VELIKOVA, V., SALERNO, G., FRATI, F., PERI, E., CONTI, E., COLAZZA, S. and LORETO, F., 2010. Influence of feeding and oviposition by phytophagous pentatomids on photosynthesis of herbaceous plants. Journal of Chemical Ecology, vol. 36, no. 6, pp. 629-641. http://dx.doi.org/10.1007/s10886-010-9801-7. PMid:20490900.

YAN, F., BENGTSSON, M., ANDERSON, P., ANSEBO, L., XU, C. and WITZGALL, P., 2004. Antennal response of cotton bollworm (Helicoverpa armigera) to volatiles in transgenic Bt cotton. Journal of Applied Entomology, vol. 128, no. 5, pp. 354-357. http://dx.doi.org/10.1111/j.1439-0418.2004.00857.x. 